\title{
Genetic Variability, Heritability, Correlation and Path Coefficient Studies for Yield and Yield Components of Some Promising Rice Hybrids
}

\author{
A Akter ${ }^{*}$, M J Hasan ${ }^{1}$, M A Latif ${ }^{2}$, M U Kulsum¹, P L Biswas' ${ }^{1}$, M H Rahman ${ }^{1}$, \\ R R Majumder ${ }^{3}$, L F Lipi', M R Quddus ${ }^{1}$, F Akter ${ }^{3}$, A Ara ${ }^{2}$
}

\begin{abstract}
Eight promising hybrids along with three checks were evaluated for yield and yield contributing traits to observe their genetic variability, heritability, correlation and path coefficient analysis during T. Aman season 2014. The results indicated that the highest genotypic variance was recorded in spikelet panicle-1 followed by effective tiller $\mathrm{m}^{-2}$. Similarly, the highest phenotypic variances were also found with these two characters. Phenotypic coefficient of variation (PCV) was slightly higher than genotypic coefficient of variation (GCV) for all the traits under this study. Hence, slight differences indicate less or minor environmental influence and greater role of genetic factors on the expression of the traits. High heritability was observed in all the characters studied except effective tiller $\mathrm{m}^{-2}$. Highly significant and positive correlations of grain yield with effective tiller $\mathrm{m}^{-2}$, spikelet panicle-1 at genotypic level were observed. Spikelet fertility was found significant at both genotypic and phenotypic level. Path analysis revealed that spikelet fertility had highly positive direct effect on grain yield followed by effective tiller $\mathrm{m}^{-2}$. On the other hand, spikelet panicle-1 showed positive indirect effect on grain yield. Thus, the results suggested that effective tiller $\mathrm{m}^{-2}$; number of spikelet panicle $^{-1}$ and spikelet fertility (\%) could be considered as effective selection criteria for the development of heterotic rice hybrids.
\end{abstract}

Key words: Genetic variability, heritability, correlation, path analysis, hybrid rice

\section{INTRODUCTION}

Rice occupies more than $75.01 \%$ of total cropped area of Bangladesh (BBS, 2015). It provides $75 \%$ of the calories and $55 \%$ of the proteins in the average daily diet of the people (Bhuiyan et al., 2002). Bangladesh is one of the most densely populated countries of the world. To feed the ever increasing population, there is no option other than breaking the yield ceiling of rice. Hybrids may offer to make a breakthrough in the yield ceiling of semidwarf rice that began in 1964. Currently, hybrid rice technology is considered as a viable option to increase rice yield globally. China is the first country to exploit of heterosis commercially in rice. During late 90s, about $55 \%$ of the rice area in China was under hybrid rice, producing $66 \%$ of the total rice production (Virmani et al., 1998). At present, hybrid rice covers $70 \%$ of the total rice area which is about 20 million hectares. The most promising hybrids yielded $20-30 \%$ and $15-20 \%$ (Yuan, 1998) higher than the best conventional and modern rice varieties, respectively. Initially, after the introduction of hybrid rice in Bangladesh in 1998, over the last one and half decades, about 174 rice hybrids were released for commercial cultivation in different rice growing regions of the country (SCA, 2018). The estimated area under hybrid rice in Bangladesh is about $0.7 \mathrm{M}$ ha has contributed 3-4 MT of additional rice to the total rice production in the country (AIS, 2018).

Grain yield is a complex trait, controlled by many genes, environmentally influenced and determined by the magnitude and nature of their genetic variability in which they grow

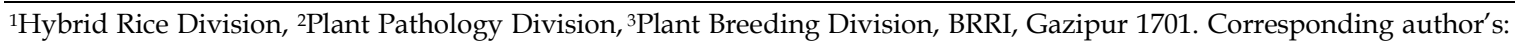
anowaraa@yahoo.com 
(Singh et al., 2000 and Selvaraj et al., 2011). Hence, direct selection for yield is often misleading. Therefore, the characters, which are closely related to grain yield contribution, were identified (Rangare et al., 2012). Genetic variation is the basis of plant breeding and provides a great array of genotypes that can be selected to develop new varieties or breeding materials (Pandey et al., 2009). Variability in terms of genetic divergence for agronomic traits is the component of breeding programmes for broadening the gene pool of rice and requires reliable estimates of heritability to plan an efficient breeding strategy (Akinwale et al., 2011). Path coefficient analysis partitions the genetic correlation between yield and its component traits into direct and indirect effects and hence has effectively been used in identifying useful traits as selection criteria to improve grain yield in rice (Sadeghi, 2011; Lakshmi et al., 2017 and Singh et al., 2018). Genetic improvement of plants for quantitative traits requires reliable estimates of heritability in order to plan an efficient breeding programme. The broad sense heritability is the relative magnitude of genotypic and phenotypic variance for the traits and it gives an idea of the total variation accounted to genotypic effect (Allard, 1960). Correlation coefficient determines the simple relations among the traits. It does not always determine decisive result about determination of plant selection criteria. But path coefficient analyses as well as correlation coefficient give more detailed information on the relations among the yield and yield contributing traits. Present research was conducted to evaluate the heritability and genetic advance for grain yield and some of its related components in order to select the more effective traits which may contribute for the improvement of hybrid rice. This experiment also aimed to study the variation of important agronomic traits and identify the characters of utmost importance which could be used as selection criteria in a hybrid rice breeding programme and to determine the direct and indirect contributions of important yield components on yield.

\section{MATERIALS AND METHODS}

\section{Experimental site, seasons, materials and procedures}

The experiment was conducted at the experimental farm of BRRI, Gazipur during July to November in T. Aman season 2014. Nine promising rice hybrids viz. IR79156A/BRRI20R, IR79156A/BasmatiR, IR58025A/BasmatiR, Jin23A/BasmatiR, BRRI7A/BRRI31R, BRRI28A/BRRI31R, BRRI33A/BRRI31R, BRRI28A/BRRI26R and three conventional checks viz BRRI dhan49, BR11, BRRI hybrid dhan4 were used as experimental materials in this study. All the promising hybrids along with three checks were sown separately into well prepared seed bed. Twenty-one-day old seedlings were transplanted with a spacing of $15 \mathrm{~cm}$ between plants and $20 \mathrm{~cm}$ between rows with single seedling per hill in the main field in randomized complete block (RCB) design with three replications. The plot size was $5 \times 4 \mathrm{~m}^{2}$. Fertilizers were applied @ 150:100:70:60:10 kg ha-1 Urea, TSP, MP, gypsum and $\mathrm{ZnSO}_{4}$, respectively. Standard agronomic practices were followed and plant protection measures were taken as required following (Anonymous, 2014).

\section{Data collection}

An observation and data record for all traits studied was made based on the Standard Evaluation System for rice (IRRI, 1996). Five sample plants were selected randomly in the middle three rows from each plot and observations were recorded on days to maturity, plant height $(\mathrm{cm})$, number of effective tiller $\mathrm{m}^{-2}$, number of spikelet panicle ${ }^{-1}$, panicle length $(\mathrm{cm})$, spikelet fertility $(\%)$, panicle weight $(\mathrm{g})$, thousand grain weight $(\mathrm{g})$, grain yield (ton hectare ${ }^{-1}$ ) and moisture content of grains were measured by moisture meter and adjusted at $14 \%$ moisture content. Two border rows were used to minimize the border effects. 


\section{Statistical analysis}

Analysis of variance was performed using the plant breeding statistical programme MSTAT $\mathrm{C}$ software. The genotypic and phenotypic variance, genotypic coefficient of variation (GCV), phenotypic coefficient of variation $(\mathrm{PCV})$, heritability in broad sense $\left(\mathrm{h}^{2} \mathrm{~b}\right)$, genetic advance in percentage of mean (GA), genotypic correlation coefficients $\left(r_{g}\right)$ and phenotypic correlation coefficients $\left(r_{p}\right)$ analysis were estimated following (Singh and Chaudhary, 1985). The estimates of GCV and PCV were classified as low, medium and high (Sivasubramanian and Madhavamenon, 1973). Heritability in broad sense and genetic advance were calculated according to methods given by (Allard, 1960). Path coefficient analysis was done using R-software (Ri386 3.1.2)

\section{RESULTS AND DISCUSSION}

\section{Variation and performance of the genotypes}

The analyses of variance of nine important quantitative characters for different genotypes showed significant variations among the genotypes for days to maturity, plant height (cm), effective tiller $\mathrm{m}^{-2}$, no. of spikelet panicle1 , panicle length $(\mathrm{cm})$, spikelet fertility $(\%)$, panicle weight $(\mathrm{g})$, thousand grain weights $(\mathrm{g})$ and yield ( $\mathrm{t} \mathrm{ha} \mathrm{h}^{-1}$ ) (Table 1$)$. These results indicated that there were genotypic variations among the genotypes for these characters.

\section{Genetic variability}

Table 2 shows that the highest genotypic variance was obtained in spikelet panicle ${ }^{-1}$ followed by effective tiller $\mathrm{m}^{-2}$. Similarly the highest phenotypic variances were also obtained for those two characters. On the other hand, the lowest magnitude of genotypic and phenotypic variance was recorded in panicle weight and panicle length respectively. This might be due to the presence of both positive and negative alleles in the hybrids studied. Similar results were reported by Iftekharuddaula et al. (2001). The extent of variability for any character is very important for the improvement of a crop through breeding. The variability of the characters was measured by range, genotypic coefficient of variation (GCV) and phenotypic coefficient of variation $(\mathrm{PCV})$. The estimates of phenotypic coefficient of variation were slightly higher than those of genotypic coefficient of variation (GCV) for all the traits studied. The extent of the environmental influence on traits is explained by the magnitude of the difference between GCV and PCV. Large differences between GCV and PCV values reflect high environmental influence on the expression of traits. In this study, slight differences indicated environmental influence and consequently greater role of genetic factors on the expression of traits. Similar observations were also noted earlier by Mustafa and Elsheikh (2007) and Kole et al. (2008) in rice.

Table 1. Mean squares analysis for morphological traits in promising hybrid rice.

\begin{tabular}{lclllllllll}
\hline Character & df & $\begin{array}{l}\text { Days to } \\
\text { maturity }\end{array}$ & $\begin{array}{l}\text { Plant } \\
\text { height } \\
(\mathrm{cm})\end{array}$ & $\begin{array}{l}\text { Effective } \\
\text { tiller } \mathrm{m}^{-2}\end{array}$ & $\begin{array}{l}\text { Spikelet } \\
\text { panicle }-1\end{array}$ & $\begin{array}{l}\text { Panicle } \\
\text { length } \\
(\mathrm{cm})\end{array}$ & $\begin{array}{l}\text { Spikelet } \\
\text { fertility } \\
(\%)\end{array}$ & $\begin{array}{l}\text { Panicle } \\
\text { weight } \\
(\mathrm{g})\end{array}$ & $\begin{array}{l}\text { TGW } \\
(\mathrm{g})\end{array}$ & $\begin{array}{l}\text { Yield } \\
\left.(\mathrm{t} \mathrm{ha})^{-1}\right)\end{array}$ \\
\hline Genotypes & 10 & $387.89^{* *}$ & $87.38^{* *}$ & $2157.44^{* *}$ & $2344.38^{* *}$ & $6.75^{* *}$ & $55.59^{* *}$ & $2.71^{* *}$ & $31.64^{* *}$ & $3.21^{* *}$ \\
Replication & 2 & 0.21 & 5.68 & 425.08 & 58.30 & 0.79 & 5.83 & 0.01 & 0.00 & 0.26 \\
Error & 20 & 0.17 & 12.89 & 671.90 & 172.65 & 0.61 & 2.29 & 0.00 & 0.00 & 0.07 \\
CV (\%) & 0.37 & 3.05 & 11.44 & 6.66 & 3.00 & 1.85 & 1.42 & 0.17 & 4.93 \\
\hline
\end{tabular}

\footnotetext{
*Significant at the 5\% level of probability; ** Significant at the 1\% level of probability; TGW= Thousand grain weight.
} 
Table 2. Estimate of genetic parameters for grain yield and its contributing traits of promising hybrid rice.

\begin{tabular}{|c|c|c|c|c|c|c|c|c|c|}
\hline Character & Maximum & Minimum & Mean & $\begin{array}{l}\text { Genotypic } \\
\text { variance }\end{array}$ & $\begin{array}{l}\text { Phenotypic } \\
\text { variance }\end{array}$ & $\begin{array}{l}\text { GCV } \\
(\%)\end{array}$ & $\begin{array}{l}\text { PCV } \\
(\%)\end{array}$ & $h^{2} b$ & GA \\
\hline $\begin{array}{l}\text { Days to } \\
\text { maturity }\end{array}$ & 140.00 & 102.00 & 114.303 & 129.239 & 129.418 & 9.95 & 9.95 & 99.86 & 23.40 \\
\hline $\begin{array}{l}\text { Plant height } \\
\text { (cm) }\end{array}$ & 129.20 & 106.20 & 117.679 & 24.828 & 37.724 & 4.23 & 5.22 & 65.82 & 8.33 \\
\hline $\begin{array}{l}\text { Effective } \\
\text { tiller } \mathrm{m}^{-2}\end{array}$ & 283.80 & 158.00 & 226.539 & 495.180 & 1167.081 & 9.82 & 15.08 & 42.43 & 29.86 \\
\hline $\begin{array}{l}\text { Spikelet } \\
\text { panicle }^{-1}\end{array}$ & 249.00 & 133.00 & 197.424 & 723.911 & 896.557 & 13.63 & 15.17 & 80.74 & 49.80 \\
\hline $\begin{array}{l}\text { Panicle } \\
\text { length }(\mathrm{cm})\end{array}$ & 29.20 & 22.20 & 25.970 & 2.047 & 2.654 & 5.51 & 6.27 & 77.13 & 2.59 \\
\hline $\begin{array}{l}\text { Spikelet } \\
\text { fertility (\%) }\end{array}$ & 87.00 & 70.00 & 81.670 & 17.765 & 20.060 & 5.16 & 5.48 & 88.56 & 8.17 \\
\hline $\begin{array}{l}\text { Panicle } \\
\text { weight (g) }\end{array}$ & 5.20 & 2.18 & 3.687 & 0.904 & 0.907 & 25.78 & 25.83 & 99.67 & 1.96 \\
\hline $\begin{array}{l}\text { Thousand } \\
\text { grain weight } \\
\text { (g) }\end{array}$ & 32.10 & 20.43 & 25.66 & 10.546 & 10.548 & 12.65 & 12.65 & 99.98 & 6.69 \\
\hline Yield $\left(\mathrm{t} \mathrm{ha}^{-1}\right)$ & 6.84 & 2.59 & 5.374 & 1.046 & 1.116 & 19.03 & 19.66 & 93.73 & 2.04 \\
\hline
\end{tabular}

\section{Heritability}

The estimates of broad sense heritability varied from 42.43 to $99.98 \%$ (Table 2). High heritability was observed in all the characters except effective tiller $\mathrm{m}^{-2}$. Although high heritability suggests high component of heritable portion of variation that can be exploited by breeders in the selection of superior genotypes (Ali et al., 2002). On the basis of phenotypic performance, heritability estimates along with genetic advance will be more useful in predicting the effect for selecting the best individual. Effective tiller $\mathrm{m}^{-2}$ exhibited moderate heritability which indicates the possibility of using for rice improvement programme but their expression can be influenced more by the environment. High to moderate heritability was reported for different quantative traits in rice (Zahid et al., 2006; Kole et al., 2008; Khan et al., 2009 and Sadeghi, 2011). The estimate of genetic advance as percent of mean (Table 2) was high for spikelet panicle-1, effective tiller $\mathrm{m}^{-2}$ and days to maturity; moderate for plant height, spikelet fertility and thousand grain weight; and very low for panicle length, panicle weight and yield. Therefore, the characters, viz effective tiller $\mathrm{m}^{-2}$, spikelet panicle ${ }^{-1}$, spikelet fertility and thousand grain weight (TGW) with moderate to high heritability and genetic advance could be considered effective traits in selection of $\mathrm{F}_{1}$ genotypes. Similar result was reported by Iftekharuddaula et al. (2001). However, effective tiller $\mathrm{m}^{-2}$ and spikelet panicle $^{-1}$ could be the most effective selection criteria as these characters had high genotypic and phenotypic variance in addition to high genetic advance.

\section{Correlation coefficient}

Table 3 presents genotypic and phenotypic correlation coefficient among grain yield and yield components for promising rice hybrid. Genotypic correlation coefficients were found higher than the phenotypic correlation coefficients in most of the cases which suggested that character association had not been largely influenced by environmental factors. There were highly significant and positive correlations of grain yield with spikelet fertility both at genotypic and phenotypic levels. On the other hand, effective 
tiller $\mathrm{m}^{-2}$ and spikelet panicle ${ }^{-1}$ were significant and positive correlation of grain yield at genotypic levels, indicating the importance of these traits for yield improvement. The results are in agreement with Rokonuzzaman et al. (2008) and Khan et al. (2009) for spikelet panicle $^{-1}$, Kole et al. (2008) and Qamar et al. (2005) for effective tiller $\mathrm{m}^{-2}$ and Ramakrishman et al. (2006) for spikelet fertility. Grain yield had positive and nonsignificant correlation in days to maturity, plant height, panicle length and thousand grain weight both at genotypic and phenotypic levels. Similar observations were reported for panicle length by Kole et al. (2008). On the contrary, Khan et al. (2009) and Qamar et al. (2005) reported positive and non-significant association between grain yield and days to maturity. In our present study yield showed negative and non-significant association with panicle weight both at genotypic and phenotypic levels.
Interrelationships among yield contributing characters showed both significant positive and negative correlation. Days to maturity possesses significant and negative correlation with panicle length and TGW at both genotypic and phenotypic level. Plant height had significant and positive correlation with thousand grain weight at both genotypic and phenotypic level. Significant and positive correlation was observed for effective tiller $\mathrm{m}^{-2}$ with spikelet fertility and grain yield at genotypic level only. It was observed that there were significant and positive correlations of spikelet panicle ${ }^{-1}$ with spikelet fertility at both genotypic and phenotypic level but with grain yield at genotypic level only. Panicle length was highly significant and positive correlation with TGW was at both genotypic and phenotypic level. Finally, panicle weight showed significant and positive correlation with TGW at both the levels.

Table 3. Genotypic (G) and phenotypic (P) correlation coefficients among yield and yield components for promising hybrid rice.

\begin{tabular}{|c|c|c|c|c|c|c|c|c|c|}
\hline Character & & $\begin{array}{l}\text { Plant } \\
\text { height } \\
(\mathrm{cm})\end{array}$ & $\begin{array}{l}\text { Effective } \\
\text { tiller } \mathrm{m}^{-2}\end{array}$ & $\begin{array}{l}\text { Spikelet } \\
\text { panicle-1 }^{-1}\end{array}$ & $\begin{array}{l}\text { Panicle } \\
\text { length } \\
(\mathrm{cm})\end{array}$ & $\begin{array}{c}\text { Spikelet } \\
\text { fertility } \\
(\%)\end{array}$ & $\begin{array}{l}\text { Panicle } \\
\text { weight } \\
\text { (g) }\end{array}$ & TGW (g) & $\begin{array}{l}\text { Yield } \\
\left(\mathrm{t} \mathrm{ha}^{-1}\right)\end{array}$ \\
\hline \multirow{2}{*}{ Days to maturity } & G & -0.1087 & 0.2170 & 0.2859 & $-0.8804^{* *}$ & 0.4890 & 0.0369 & $-0.7110^{*}$ & 0.0785 \\
\hline & $\mathrm{P}$ & -0.0843 & o.1475 & 0.2576 & $-0.7728^{* *}$ & 0.4602 & 0.0364 & $-0.7102^{*}$ & 0.0739 \\
\hline \multirow[t]{2}{*}{ Plant height (cm) } & G & & -0.2872 & 0.1091 & 0.2123 & 0.2337 & 0.5690 & $0.8859^{* *}$ & 0.1875 \\
\hline & $\mathrm{P}$ & & -0.0557 & 0.2318 & 0.2456 & 0.1756 & 0.4549 & $0.7206^{*}$ & 0.1332 \\
\hline \multirow[t]{2}{*}{ Effective tiller $\mathrm{m}^{-2}$} & G & & & 0.5439 & -0.1765 & $0.7178^{*}$ & -0.2841 & -0.3622 & $0.8275^{* *}$ \\
\hline & $\mathrm{P}$ & & & 0.3323 & -0.0445 & 0.4888 & -0.1630 & -0.2322 & 0.4532 \\
\hline \multirow[t]{2}{*}{ Spikelet panicle-1 } & G & & & & -0.0633 & $0.6681^{*}$ & 0.2028 & 0.2453 & $0.5669^{*}$ \\
\hline & $\mathrm{P}$ & & & & -0.0235 & $0.5598^{*}$ & 0.1817 & 0.2219 & 0.4707 \\
\hline \multirow{2}{*}{$\begin{array}{l}\text { Panicle length } \\
\text { (cm) }\end{array}$} & G & & & & & -0.2474 & 0.0439 & $0.9589^{* *}$ & 0.2230 \\
\hline & $\mathrm{P}$ & & & & & -0.1698 & 0.0358 & $0.8415^{* *}$ & 0.1356 \\
\hline \multirow[t]{2}{*}{$\begin{array}{l}\text { Spikelet fertility } \\
(\%)\end{array}$} & G & & & & & & 0.0889 & -0.1045 & $0.9103^{* *}$ \\
\hline & $\mathrm{P}$ & & & & & & 0.0909 & -0.0992 & $0.8169^{* *}$ \\
\hline \multirow{2}{*}{ Panicle weight (g) } & G & & & & & & & $0.6943^{*}$ & -0.0021 \\
\hline & $\mathrm{P}$ & & & & & & & $0.6943^{*}$ & -0.0056 \\
\hline \multirow{2}{*}{$\begin{array}{l}\text { Thousand grain } \\
\text { weight }(\mathrm{g})\end{array}$} & G & & & & & & & & 0.1886 \\
\hline & $\mathrm{P}$ & & & & & & & & 0.1806 \\
\hline
\end{tabular}

*Significant at the $5 \%$ level of probability; ** Significant at the $1 \%$ level of probability. 


\section{Path coefficient analysis}

Genotypic correlation coefficients were partitioned by using path analysis method to find out the direct and indirect effects of yield contributing traits towards the grain yield. Path analysis (Table 4) revealed that the highest positive direct effect and genotypic correlation $\left(r_{g}=0.9103\right)$ with grain yield was obtained by spikelet fertility (1.117) followed by days to maturity (0.655), panicle length (0.404) and effective tiller $\mathrm{m}^{-2}(0.103)$. The highest positive direct effect has been reported for spikelet fertility (Agbo and Obi, 2005), days to maturity (Qamar et al., 2005), productive tillers (Agahi et al., 2005; Rokonuzzaman et al., 2008) in rice. Spikelet panicle ${ }^{-1}$ had negative direct effect with significant genetic correlation with grain yield. On the other hand, effective tiller $\mathrm{m}^{-2}$ had positive indirect effect through all the traits except thousand grain weight but days to maturity, plant height, panicle weight and spikelet panicle ${ }^{-1}$ had negatibe indirect effect on grain yield through most of the other traits. The indirect effects of spikelet fertility for other traits indicated the importance of direct selection using spikelet fertility to select high yielding genotypes. The residual effect of the present study was 0.017, indicating that about 98 percent of variability in grain yield might be contributed by these eight yield contributing traits studied in the path analysis. This gives an impression that some other minor characters than those involved in the present study also contributed to the variability of grain yield.

\section{CONCLUSION}

The estimation of genetic parameters, correlation and path coefficient of some promising hybrid rice for grain yield and yield contributing characters indicated that spikelet panicle $^{-1}$ had high both genotypic and phenotypic variance with high heritability and high genetic advance. Effective tiller $\mathrm{m}^{-2}$ had high phenotypic variance with high genetic advance. Spikelet fertility had the highest genotypic and phenotypic correlation coefficient on yield.

Table 4. Path coefficient showing direct and indirect effects of yield components on grain yield.

\begin{tabular}{|c|c|c|c|c|c|c|c|c|c|}
\hline Character & $\begin{array}{l}\text { Day to } \\
\text { maturity }\end{array}$ & $\begin{array}{l}\text { Plant } \\
\text { height } \\
(\mathrm{cm})\end{array}$ & $\begin{array}{l}\text { Effective } \\
\text { tiller } \mathrm{m}^{-2}\end{array}$ & $\begin{array}{l}\text { Spikelet } \\
\text { panicle }^{-1}\end{array}$ & $\begin{array}{l}\text { Panicle } \\
\text { length } \\
(\mathrm{cm})\end{array}$ & $\begin{array}{l}\text { Spikelet } \\
\text { fertility } \\
(\%)\end{array}$ & $\begin{array}{l}\text { Panicle } \\
\text { weight } \\
\text { (g) }\end{array}$ & $\begin{array}{l}\text { TGW } \\
(\mathrm{g})\end{array}$ & $\begin{array}{l}\text { Genotypic } \\
\text { correlation } \\
\text { with grain } \\
\text { yield }\end{array}$ \\
\hline $\begin{array}{l}\text { Day to } \\
\text { maturity }\end{array}$ & 0.655 & 0.011 & 0.034 & -0.044 & -0.031 & -0.635 & 0.008 & -0.050 & 0.0785 \\
\hline $\begin{array}{l}\text { Plant } \\
\text { height }(\mathrm{cm})\end{array}$ & 0.273 & 0.027 & -0.010 & -0.077 & 0.105 & -0.939 & 0.040 & -0.003 & 0.1875 \\
\hline $\begin{array}{l}\text { Effective } \\
\text { tiller } \mathrm{m}^{-2}\end{array}$ & 0.215 & -0.003 & 0.103 & 0.074 & 0.060 & 0.252 & 0.018 & -0.045 & $0.8275^{* *}$ \\
\hline $\begin{array}{l}\text { Spikelet } \\
\text { panicle }^{-1}\end{array}$ & 0.069 & 0.005 & -0.018 & -0.418 & 0.169 & -0.128 & 0.051 & 0.020 & $0.5669^{*}$ \\
\hline $\begin{array}{l}\text { Panicle } \\
\text { length }(\mathrm{cm})\end{array}$ & -0.051 & 0.007 & 0.015 & -0.176 & 0.404 & -0.050 & 0.049 & -0.016 & 0.2230 \\
\hline $\begin{array}{l}\text { Spikelet } \\
\text { fertility (\%) }\end{array}$ & -0.372 & -0.023 & 0.023 & 0.048 & -0.018 & 1.117 & -0.018 & -0.004 & $0.9103^{* *}$ \\
\hline $\begin{array}{l}\text { Panicle } \\
\text { weight (g) }\end{array}$ & 0.063 & 0.013 & 0.021 & -0.253 & 0.236 & -0.241 & 0.085 & -0.008 & -0.0021 \\
\hline $\begin{array}{l}\text { Thousand } \\
\text { grain } \\
\text { weight }(\mathrm{g})\end{array}$ & 0.378 & 0.001 & 0.054 & 0.096 & 0.074 & 0.046 & 0.007 & -0.087 & 0.1886 \\
\hline
\end{tabular}

Bold figures indicate the direct effect, Residual effect $=0.017$. 
On the other hand, effective tiller $\mathrm{m}^{-2}$ and spikelet panicle-1 had significant only genotypic correlation coefficient on grain yield. Spikelet fertility had high direct effect and highly significant positive correlation with grain yield followed by days to maturity, effective tiller $\mathrm{m}^{-2}$ and panicle length $(\mathrm{cm})$. Hence these four important traits, could be considered as selection criteria for the development of high yielding hybrid rice varieties.

\section{ACKNOWLEDGEMENT}

\section{Authors are thankful to all the staff members of Hybrid Rice Division}

\section{REFERENCES}

Agahi, K, E Farshadfar and M H Fotokian. 2007. Correlation and path coefficient analysis for some yield-related traits in rice genotypes (Oryza sativa L.). Asian J.Plant Sci. 6:513-517.

Agbo, C U and I U Obi. 2005.Yield and yield component analysis of twelve upland rice genotypes. J. Agric. Food, Environ. Extens. 4:29-33.

AIS. 2018. Krishi Diary. 2016. Dept. of Agricultural Information Service, Khamarbari, Farmgate, Dhaka-1215, Bangladesh.

Akinwale, A G, G Gregorio, F Nwilene, B O Akinyele, S A Ogunbayo and A C Odiyio. 2011. Heritability and correlation coefficient analysis for yield and its components in rice (Oryzae sativa L.) African J. Plant Sci. 5: 207-212.

Ali, A, S Khan and M A Asad. 2002. Drought tolerance in wheat: Genetic variation and heritability for growth and ion relations. Asian J.Plant Sci. 1:420-422.

Allard, R W. 1960. Principles of Plant Breeding. $1^{\text {st }}$ Edn. John Wiley and Sons Inc., New York.

Anonymous. 2014. Adhunik Dhaner Chash (15 edn), Bangladesh Rice Research Institute, Gazipur 1701, Bangladesh. p: 20-50.

BBS. 2015. Year Book of Agricultural Statistics of Bangladesh, Planning Division, Ministry of Planning, Govt. of the people's Republic of Bangladesh, Dhaka. pp 23-27.

Bhuiyan, N I, D N R Paul and M A Jabbar. 2002. Feeding the extra millions by 2025 challenges for rice research and extension in Bangladesh. A key note paper presented on national workshop on rice research and extension. Held on 29-31 January.BRRI. P. 9.

Iftekharuddaula, K M, M S Hassan, M J Islam, M A Badsha, M R Islam and Akter Khaleda. 2001. Genetic evaluation and selection criteria of hybrid rice in irrigated ecosystem of Bangladesh. Pakistan Journal of Biological Sciences. 4 (7): 790-792.

IRRI. 1996. Standard Evaluation System for Rice. $4^{\text {th }}$ Edn., International Rice Research Institute, Manila, Philippines.

Khan, A S, M Imran and M Ashfaq. 2009. Estimation of genetic variability and correlation for grain yield components in rice (Oryza sativa L.). Am. Eurasian J. Agric. Environ. Sci. 6:585-590.

Kole, P C, N R Chakraborty and J S Bhat. 2008. Analysis of variability, correlation and path coefficients in induced mutants of aromatic non-basmati rice. Trop. Agric. Res. Exten. 113:60-64.

Lakshmi, L, M V B Rao, C S Raju and S N Reddy. 2017. Variability, Correlation and Path Analysis in Advanced Generation of Aromatic Rice Int. J. Curr. Microbial. App. Sci. 6(7): 1798-1806.

Mustafa, M A and M A Y Elsheikh. 2007. Variability, correlation and path coefficient analysis for yield and its components in rice. Afr. Crop Sci. J. 15:183189.

Panday, P, P J Anurag, D K Tiwari, S K Yadav and B Kumar. 2009. Genetic variability, diversity and association of quantitative traits with grain yield in rice (Oryza sativa L.). J. of Bio-Science. 17(1): 77-82.

Qamar, Z U, A A Cheema. M Ashraf, M Rashid and G R Tahir. 2005. Association analysis of some yield influencing traits in aromatic and non aromatic rice. Pak. J. Bot. 37: 616-627.

Ramakrishman, S H, C R Anandakumar, S Saravanan and N Malini. 2006. Association analysis of some yield traits in rice (Oryza sativa L.). J. Applied Sci. Res. 2:402-404.

Rokonuzzaman, M M, S Zahangir and M D I Hussain. 2008. Genotypic variability of components and their effects on the rice yield: Correlation and path analysis study. Ital. J. Agron. 2:131-134.

Sadeghi, S M. 2011. Heritability, phenotypic correlation ana path coefficient studies for some agronomic characters in landrace rice varieties. World Applied Sci. J. 13:1229-1233.

SCA. 2018. List of released hybrid rice varieties from 1997 to 2018.

Selvaraj, I C, P Nagarajan, K Thiyagarajan, M Bharathi and R Rabindran. 2011. Genetic parameters of variability, correlation and path coefficient studies for grain yield and other yield attributes among rice blast disease resistant genotypes of rice (Oryza sativa L.). African J. Biotech. 10: 3322-3334.

Singh, R K and B D Chaudhary. 1985. Biometrical methods in quantitative genetic analysis. Kalayani publishers, New Delhi. 
Singh, R K, P L Gautam, S Saxena and S Singh. 2000. Scented Rice Germplasm: Conservation, Evaluation and Utilization. In: Aromatic Rice, Singh, R.K., U.S. Singh and G.S. Khush (Eds.). Oxford and IBH Publishing, New Delphi. pp: 107-133.

Sivasubramanian, S and P Madhavamenon. 1973. Genotypic and Phenotypic variability in rice. Madras Agric. J. 60: 1093-1096

Virmani, S S, P J Jachuck, S D Chatterjee and M I Ahmad. 1998. Opportunities and challenges of developing hybrid rice technology for rainfed lowland and Boro ecosystem. In: Rainfed Rice foor Sustainable
Food Security (S. K. Mohanty, ed). Cuttack, India. 533-62 pp.

Yuan, L P. 1998. Hybrid rice breeding in China. In: Advances in Hybrid Rice Technology (Virmani SS, Siddiq EA, Muralidharan K, editors). Proc. 3rd Intl. Symp. on Hybrid Rice. held on 14-16 November 1996, Hyderabad, India. 27-33 pp.

Zahid, M A, M Akhter, M Sabar, Z Manzoor and T Awan. 2006. Correlation and path analysis studies of yield and economic traits in Basmati rice (Oryza sativa L.). Asian J. Plant Sci. 5:643-645. 